\title{
Os Educadores Educarão os Educadores
}

Se captei bem a mensagem dos Professôres Rattner e José Paulo, ela afirma, em essência: a tese exposta é razoàvelmente original e coerente na sua estrutura lógica, mas não se aplica aos PMDs: a) por não existirem evidências empíricas que comprovassem a sua validade; b) por ser ingênua face ao excesso de otimismo de sua premissa básica; e c) por deixar várias questões cruciais em aberto.

Vejamos cada uma dessas objeções, pela ordem:

A. O fato de não existir evidência empírica a respeito de uma tese nem a invalida, nem a confirma. Dizem os inglêses: "A prova do pudim está em comê-lo." o pudim contudo, que só existe como receita, não pode ser comido. A tese, pois, que ainda não passou pelo crivo da experiência pode ser "boa" ou não. Antes do fato, não o sabemos.

B. A suposta premissa básica, subjacente ao artigo, ou a "idéia da educação como 'panacéia' universal para os problemas do desenvolvimento" é uma inferência dos estimados colegas que absolutamente não endosso, nem creio que o artigo sugira ao leitor atento. As duas seçōes introdutórias e o primeiro parágrafo das conclusões procuram, entre outras coisas, sensibilizar o leitor para que não sucumba a êsse tipo de exagêro.
Talvez o artigo reflita um excesso de otimismo por defender uma tese de difícil implementação. Talvez 0 texto peque por năo ter focalizado a natureza e o grau de dificuldade na implementação da filosofia proposta. Deixamos isto para uma outra ocasião. No momento, trata-se em tentar abrir uma perspectiva.

C. Nas passagens finais, os comentaristas formulam algumas perguntas que 0 artigo deixa em aberto. Com uma dose de imaginação e desde que se aceite a tese como uma proposta meritória de investigação, não é difícil encontrarem-se respostas viáveis a essas indagações. Antes, porém, convém "filtrá-las" de algumas conotações de teor semântico algo amargo e pouco propícias à investigação científica objetiva.

Não se trata de adotar uma "postura paternalista e autoritária em relação à educação", nem de educar "donos da verdade" ou de impor objetivos e valôres em defesa de determinados "interêsses", mas de procurar uma filosofia da educação que ajude uma nação nova a encontrar os seus próprios caminhos de desenvolvimento. Dependendo da herança cultural e dos alvos de desenvolvimento imaginados pelos líderes intelectuais, sociais, políticos e econômicos, tanto a filosofia quanto as formas de sua implementação terão que variar de sociedade em sociedade. 
Para o caso já mais específico daqueles países latino-americanos que se sentem preparados a não só tentar uma formulação nesse sentido, mas procurar, também, investigar algumas modalidades de aplicação, o artigo propõe recomendações. Essas se referem a um tipo de socialização (não só de educação) que é derivado dos princípios da modernização e que, a nosso ver, poderia ser íncutido à população pelo Estado por meio do sistema educacional.

A luz dessa concepção, passemos a oferecer uma interpretaçăo telegráfica às dúvidas - justas e importantes - levantadas pelos Professôres Rattner e José Paulo:

- Estaria o Estado em condições de exercer as funções de orientador $e$ tutor da reforma valorativa moderni- zante? - Nunca, sem um devido preparo.

- A quem caberia a tarefa de prepará-la? - Aos que têm condições de fazê-lo.

- Quem seriam? - Nos PMDs, minorias crescentes, capazes e dispostas a adotar e divulgar uma filosofia modernizante.

- Que minorias seriam estas? Grupos compostos de líderes de opinião, de pessoas educadas e de educadores que, por aprendizagem e experiência, passam a ter condições de transmitir as mensagens da modernização.

- Haverá consenso entre êsses grupos? - Nunca total. Nem isto seria necessário, desde que todos lou a maioria) adotassem uma linha de conduta capaz de conciliar motivações pessoais e grupais em tôrno de um alvo comum.

- Que alvo seria êsse? - Por exemplo, o desejo de desenvolvimento aliado à disposição de lutar pela sa. tisfação dêsse desejo.

- Esse processo levaria tempo? No mínimo decênios, possivelmente gerações.

- E quem educaria os educadores? - Os educadores mais influentes e mais experimentados que adotam a filosofia da modernização.

- Não seria tudo ísto algo utópico para a América Latina? - Martin Buber escreveu: "Não é lícito chamar de utópico aquilo que ainda não foi submetido ao exame das nossas fôrças".

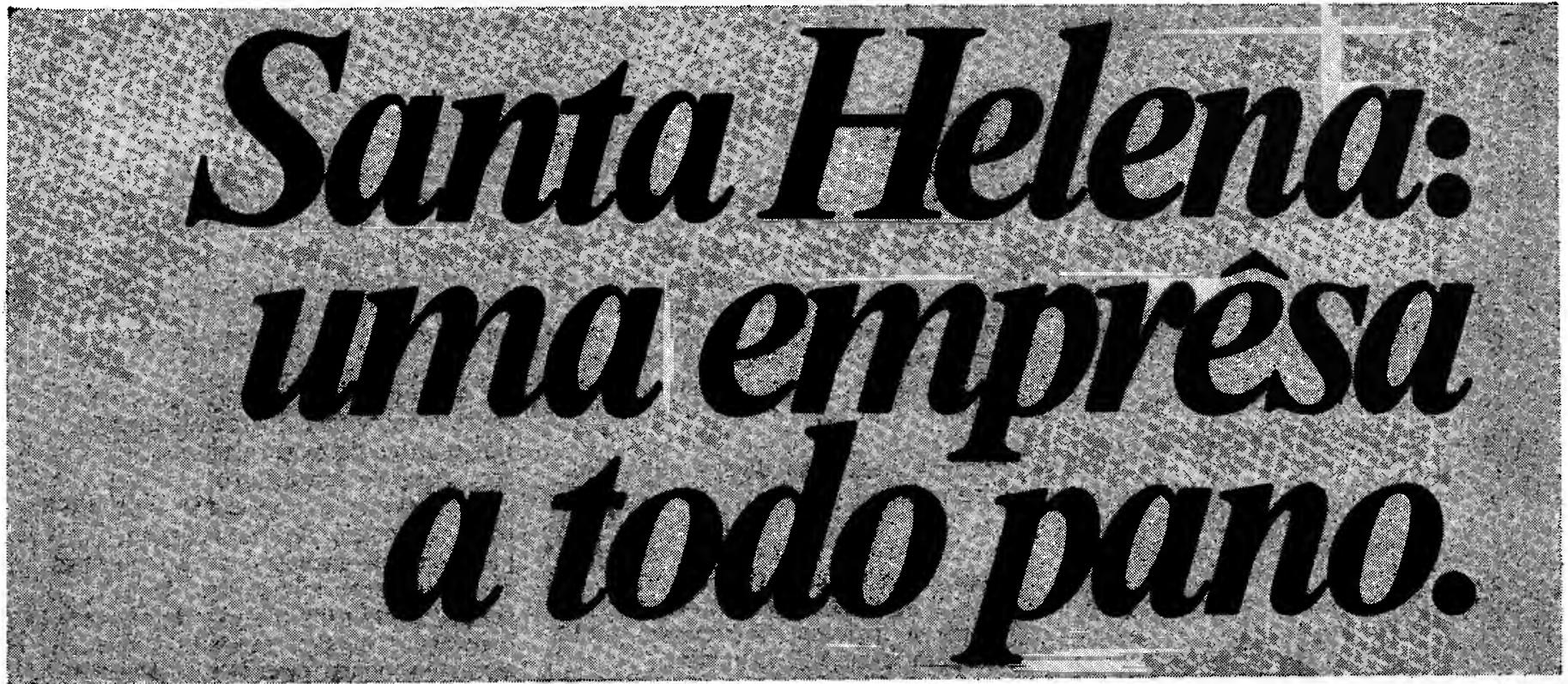

Santa Helena começou a fabricar tecidos em 1909. E ràpidamente se firmou como criadora de tecidos de alta classe. De grande qualidade. Atualmente, ela está mais viva do que nunca. Produzindo a todo pano, tecidos que fazem a moda. Santa Helena - uma emprêsa de bom gôsto.

\section{S.A. FABRICA DE TECIDOS sy SantaHelena}

Petrópolis - R.J. 